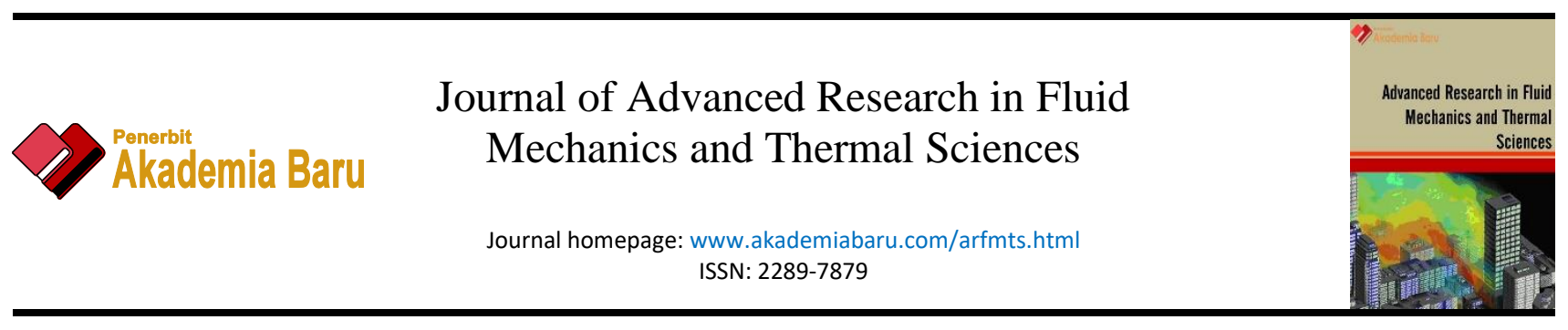

\title{
Thermal Conductivity and Dynamic Viscosity of Nanofluids: A Review
}

\author{
Wahaizad Safiei ${ }^{1,},{ }^{*}$, Md Mustafizur Rahman², Ratnakar Kulkarni ${ }^{3}$, Md Noor Ariffin ${ }^{4}$, Zetty Akhtar \\ Abd Malek ${ }^{2}$
}

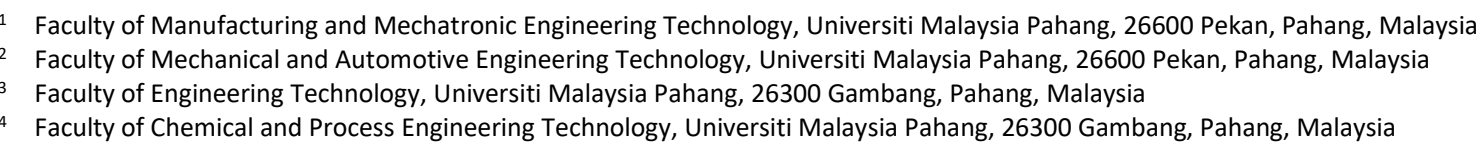

\section{ARTICLE INFO}

\section{Article history:}

Received 18 December 2019

Received in revised form 10 June 2020

Accepted 15 June 2020

Available online 15 August 2020

\section{ABSTRACT}

Thermal conductivity is one of the rheology properties that vital for engineering fluid which indispensable for heat transfer enhancement. For this reason, nanofluid is getting wider attention nowadays due to the presence of nanoparticles in the base fluid can further improve thermal conductivity and dynamic viscosity. These are two important properties for new engineering fluid in providing better cooling and lubricating effects, especially in mechanical and tribology applications. In this paper, specifically, nanofluids thermal conductivity and dynamic viscosity are discussed comprehensively. Both properties' thermal conductivity and viscosity of nanofluids are improved over the base fluid. Furthermore, these two properties increase when more volume concentrations of nanoparticles are added. In addition, the thermal conductivity also improved with increasing the temperature. From the literature review, the maximum enhancement of thermal conductivity for single nanofluid is recorded $36 \%$ of MWCNTs in distilled water. On the other hand, the maximum enhancement of viscosity is recorded $39 \%$ of $\mathrm{Al} 2 \mathrm{O} 3$ in water-ethylene glycol over base fluid. The hybrid nanofluids that consist of more than one type of nanoparticles exhibit better thermal conductivity where the maximum enhancement is recorded $68 \%$ of $\mathrm{Cu}$ $\mathrm{TiO} 2$ in deionized water. For dynamic viscosity measurement, the maximum enhancement of hybrid nanofluids is recorded $168 \%$ of MgO-MWCNT in ethylene glycol. Therefore, to sum up, hybrid nanofluids are really promising to enhance heat transfer performance especially for heating and cooling applications. The potential of these nanofluids should be explored extensively to discover its advantages over conventional working fluid.

\section{Keywords:}

Thermal conductivity; dynamic viscosity; nanofluids; heat transfer; enhancement

\footnotetext{
${ }^{*}$ Corresponding author.

E-mail address: wahaizad.safiei@gmail.com
} 


\section{Introduction}

Driven by green technology and long-term manufacturing sustainability, nanofluids are introduced as an alternative to the conventional fluid. Nanofluids are engineered colloidal suspension for minimizing environmental effects as well as for enhancing working fluid thermal and rheology properties. This is an innovative approach for new generation working fluid. Lubrication plays a vital role in the mechanical component's movement as it can reduce the friction and subsequently reduce mechanical forces. It has been reported that lubrication was found 4000 years ago in Egypt based on a large statue of a man pouring a kind of liquid [1]. Conventional liquids possess limited thermal conductivity, environmental pollution and worker's health issues that needs to resolve. Therefore, in the last 20 years ago the efforts have been devoted to coming up with the solution. Since then, a single nanofluid was introduced by the researchers and hybrid nanofluid also presented for the first time in 2015. The term "Nanofluid" was first introduced by Choi in 1995 [2]. Nanofluid by definition is referred as a working fluid that contains colloidal mixture of metallic or non-metallic nanomaterial with the particle size less than 100nm [3]. Research on nanoparticles has been increased rapidly by employing different types of nanosized materials with different volume concentrations particularly for various applications such as machining, heat exchanger, radiator, refrigerator, air-conditioner and electronics cooling. In recent years, nanofluids are prepared using different types of nanoparticles such as $\mathrm{Al}_{2} \mathrm{O}_{3}, \mathrm{ZnO}, \mathrm{TiO}_{2}, \mathrm{CNT}, \mathrm{SiO}_{2}$ and $\mathrm{ZrO}_{2}$. These materials can be considered inexpensive and yet demonstrate better thermal-physical properties. The thermal properties or convective heat transfer coefficient of base oil can further be enhanced using nanomaterials mainly due to the thermal transport capability of each particle. The performance of nanofluid in carrying heat from the heat source depends on its thermal conductivity, specific heat, viscosity and density [4]. Besides, the nanoparticle's shape also significantly influences the thermal conductivity and dynamic viscosity of the fluid [5]. According to Pryazhnikov et al., [6] there is a direct proportional relationship between particle size and thermal conductivity. The thermal conductivity of nanofluid is improved remarkably when the thermal conductivity of the base fluid is lower. The solid heat transfer performance is better compared with the liquid heat transfer performance. This is attributed to the mass molecule motion when nanofluid is circulating throughout the system which resulting in higher thermal conductivity enhancement of nanofluids.

The volume percentage or weight percentage of nanoparticles dispersed in based-oil is between $0.25 \%$ and $5 \%$ for nanofluids preparation. It has been reported that the presence of SWCNTs dispersed in the base coolant can increase the thermal conductivity of up to $105 \%$ at 1 vol\% of nanoparticle [7]. Thus, the heat is transferred more effectively from the cutting zone and subsequently the temperature can be reduced outstandingly. Fotowat et al., [8] discovered that about $17 \%$ of thermal conductivity enhancement of nanofluids over a base fluid. However, there was a corrosion effect in Aluminium and Copper however, it was negligible in Stainless Steel when all these materials were submerged in the $\mathrm{Al}_{2} \mathrm{O}_{3}$ nanofluid. Rashmi et al., [9] also studied the effects of corrosion using carbon wall nanotube nanofluids and various base fluids. On the other hand, nanofluid viscosity increases with increasing of nanoparticle diameter size and volume concentration however, decreases drastically in increasing temperature [10]. Murshed and Estelle [11] suggested that the study of nanofluid viscosity should also consider $\mathrm{pH}$ value, nanoparticle size and shape as the published articles are limited. According to Nabil et al., [12], more research is needed to understand the behavior of nanofluid including its characteristics and suitability in engineering applications. Therefore, in this paper, specifically, nanofluids thermal conductivity and dynamic viscosity are discussed comprehensively. The objective is to explore and expand the knowledge of 
nanofluids in terms of preparation, thermal-physical behavior and its modeling as well as application potential in the near future.

\section{Base Fluid}

Base fluid or single-phase liquid exhibits low thermal conductivity in which the effectiveness of heat transfer could not be obtained. This is the reason that researchers have attempted to enhance thermal-physical properties by introducing second-phase liquid such as single and hybrid nanofluid. The selection of base fluid is vital in preparing nanofluids in order to obtain nanofluids stability and enhancing its thermal-physical properties. There are many types of base fluid that are commonly used nowadays to prepare nanofluids such as water, deionized water, ethylene glycol (EG), vegetable oil, a mixture of water and ethylene, etc. Each of these base fluids has its own advantages. For instance, Ethylene Glycol is commonly used as anti-freeze addictive due to it able to further reduce the freezing temperature of working liquid $\left(0^{\circ} \mathrm{C}\right.$ to $\left.-12^{\circ} \mathrm{C}\right)$ for circulating the liquid particularly in heating and cooling systems [13]. Nazari et al., [14] revealed that a 30\% volume of Ethylene Glycol in the nanofluids has better cooling performance than $50 \%$ volume of Ethylene Glycol. It was recommended by Lim et al., [15] to mix water and ethylene glycol of 60:40 ratios as the base fluid for cooling purposes. The vegetable oil-based fluid is one of many alternative lubricants that can be considered as base fluid due to some reasons. For example, Wang et al., [16] revealed that palm oil has better lubrication properties compared to other vegetable oils. Commonly known for biodegradability and low production cost, it also has good lubrication properties [17]. Furthermore, it has great potential as metal cutting liquid which needs to be explored [18]. Synthetic or mineral oils display good lubrication properties; however, they possess lower thermal properties which not suitable for the metal cutting process that generates high temperature at the cutting zone especially under high-speed machining [17]. According to Xuan and Li [19], oil-based nanofluid was better than water-based nanofluid in terms of heat transfer characteristics. Minh et al., [20] mentioned that based on comprehensive studies emulsion 5\% coolant was more effective than soybean oil in enhancing hard milling performance in terms of surface roughness, cutting forces and the tool life.

\subsection{Nanomaterial}

The characteristics of nanomaterials depend on their size, shape, physical properties and dispersibility. The nanoparticles can be divided into three groups which are based on its physical characteristics such as (i) Metallic particles like $\mathrm{Fe}, \mathrm{Al}, \mathrm{Cu}, \mathrm{Au}, \mathrm{Ag}$, (ii) Non-metallic or metal carbide particles like $\mathrm{Al}_{2} \mathrm{O}_{3}, \mathrm{CuO}, \mathrm{SiC}, \mathrm{TiO}_{2}$ and (iii) Carbon Nanotubes [21]. The size of the particle should be less than $100 \mathrm{~nm}$ to be considered as a nanoparticle. The effectiveness of lubricating properties depends on the smaller size of nanoparticle which can form a protective film layer and subsequently reduce the friction between the cutting tool and workpiece during the machining process. Nanomaterials have a high ratio of surface area over their weight and possess anti-friction properties in base fluids [22]. According to Zhang et al., [23], MoS 2 nanoparticles show good lubrication performance, while CNTs were able to increase the heat transfer coefficient. By dispersing both nanomaterials into a base fluid, it would enhance the thermo-physical properties of nanofluid. Similarly, findings by Wang et al., [24] $\mathrm{Al}_{2} \mathrm{O}_{3}, \mathrm{MoS}_{2}$, and $\mathrm{SiO}_{2}$ have better lubricating properties when grinding Nickel Alloy $\mathrm{GH} 4169$. It has been reported that $\mathrm{Fe}_{3} \mathrm{O}_{4}$ nanoparticles exhibited the maximum thermal conductivity enhancement of $200 \%$ in water [25]. Vafaei et al., [26] revealed that the maximum enhancement of thermal conductivity of $48 \%$ was associated with $\mathrm{Fe}_{3} \mathrm{O}_{4}$ nanoparticles. Similarly, the maximum enhancement of the nanofluid viscosity was found almost $294 \%$ when $\mathrm{Fe}_{3} \mathrm{O}_{4}$ 
nanoparticles dispersed in ethylene glycol-water mixture [27]. Li et al., [28] evaluated the grinding performance of six different nanofluids $\left(\mathrm{MoS}_{2}, \mathrm{ZrO}_{2}, \mathrm{CNT}\right.$, polycrystalline diamond, $\mathrm{Al}_{2} \mathrm{O}_{3}$, and $\left.\mathrm{SiO}_{2}\right)$ and found that CNT nanofluids produced excellent thermal properties compared with other nanofluids. According to Guo et al., [29], carbon nanotubes have outstanding characteristics compared to other nanomaterials in terms of chemical stability, physical strength, high electrical and thermal conductivity, as well as mechanical resistance. Raju et al., [30] mentioned that multiwall carbon nanotubes (MWCNT) nanoparticles have a maximum thermal conductivity of $3000 \mathrm{~W} / \mathrm{mK}$ compared with other nanomaterials resulting in 36\% improvement of thermal conductivity on nanofluid compared to the conventional fluid. Moreover, this type of nanomaterial easily disperses in distilled water when sodium dodecyl sulfate (SDS) is added [31]. Copper metallic nanoparticles demonstrate $95 \%$ higher thermal conductivity at $400 \mathrm{~W} / \mathrm{mK}$ compared to Copper Oxide (CuO) which was at $20 \mathrm{~W} / \mathrm{mK}$ [32]. Furthermore, Aluminum oxide $\left(\mathrm{Al}_{2} \mathrm{O}_{3}\right)$ nanoparticles display better thermophysical properties compared to $\mathrm{SiO}_{2}$ and $\mathrm{TiO}_{2}$ nanofluids for the same volume concentrations whereas $\mathrm{Al}_{2} \mathrm{O}_{3}$ have lower lubrication properties [17,33]. Minh et al., [20] claimed that $\mathrm{Al}_{2} \mathrm{O}_{3}$ nanoparticles produced excellent tribological and anti-toxic properties. While Su et al., [34] mentioned that graphite nanoparticles were able to reduce anti-friction characteristics where a physical deposition layer could form on the surface thereby resulting in low friction forces. Sayuti et al., [35] revealed that the Vickers hardness of silicon dioxide $\left(\mathrm{SiO}_{2}\right)$ nanoparticle is $1000 \mathrm{kgfmm}-2$ which possesses good mechanical properties of hard and brittle particles.

\subsection{Single and Hybrid Nanofluids}

Single nanofluid is referred as a one-type nanoparticle with a certain amount of concentration dispersing into the base fluid. Single nanofluid has been received great attention since 1995 with the objective to enhance base fluid and conventional working fluid properties and subsequently improve cooling and lubricating characteristics. Yogeswaran et al., [36] applied $\mathrm{TiO}_{2}$-Ethylene Glycol nanofluid for enhancing milling performance. Esfe et al., [37] evaluated MgO/water nanofluid thermal conductivity coefficient between 0.01 and 0.03 volume fractions. In order to further enhancing the thermal-physical and rheology properties of single nanofluids, a combination of different nanoparticles dispersing into the base fluid could be the solution. Therefore, for the past few years, research on hybrid nanofluids has attracted great attention to exploring its potential. Hybrid nanofluids possess excellent thermal and rheology properties due to synergistic effect and can be prepared by two methods: (i) suspending two or more different nanoparticles in the base fluid, (ii) combining between two or more nanoparticles physically in the base fluid which is referred as hybrid material [38]. For instance, MgO-MWCNTs in EG, $\mathrm{Al}_{2} \mathrm{O}_{3}-\mathrm{SiC}$, MoS2-CNT in Synthetic Lipids and $\mathrm{Al}_{2} \mathrm{O}_{3}-$ GNP in oil-water emulsion were the hybrid nanofluids prepared in various applications $[17,23,26,39]$. This hybrid material exhibits better thermophysical properties due to the synergistic effect which does not exist in the single nanofluids. Many scholars mentioned that hybrid nanoparticles that disseminate in the base fluid produced higher heat transfer enhancement, cooling effect and antifriction performance rather than single nanoparticles in the material cutting process $[21,23,39]$. The combination of two different nanoparticles for preparing the hybrid nanofluids could produce manifesting results that able to increase heat transfer effectiveness in many engineering applications. In such, there are applications of hybrid nanofluids in heat exchanger, car radiator, rubbing process, electronics component cooling system, machining process as well as in solar energy collector [41-45]. However, the research of hybrid nanofluids for improving machining performance especially in metal cutting process are still limited, therefore more experimental work needs to be conducted in order to explore its great potential $[17,46]$. Both lubricating and cooling effects can be offered by hybrid 
nanofluids which regards the formation of thin-film on the contact interface to alleviate the cutting forces and able to demonstrate higher thermal-rheology properties that can carry the heat away from the heat source. Due to the advantages far outweigh the disadvantages, thus, the potential of hybrid nanofluid and its application in the metal cutting process is promising in the future and should be explored extensively.

\section{Thermal Conductivity of Nanofluids}

Heat can be transferred through conduction, convection and radiation. In these modes of heat transfer, the heat flows from high to low temperatures. Thermal conductivity is defined as the heat transfer rate within the temperature difference through a thickness material per unit area [47]. Thus, thermal conductivity can be described as the ability of a material to transfer the heat by conduction through it. This thermal property is critical for nanofluid to carry and dissipate the heat effectively. Subsequently, the cooling rate could be faster and the operating system would be more reliable. It essential that thermal conductivity measurement should be conducted for a new introduction of nanofluid which the objective is to discover the capability of the liquid to carry and dissipate the heat. In order to measure nanofluids thermal conductivity, thermal properties analyzer such as KD2 Pro and TC3010 can be used [14,29,49-52]. It is essential to ensure that nanofluid is stable and no particle sedimentation found when measuring thermal conductivity. Basically, the thermal conductivity can be measured by applying three different techniques; i) The transient hot-wire method, ii) Temperature oscillation method and iii) 3- - method. The main factor affecting the thermal conductivity of nanofluid is volume concentration $[48,49]$. Besides, the nanoparticle size, shape, type of base fluid, temperature and preparation technique also will influence the thermal conductivity. The enhancement of nanofluid thermal conductivity depands on volume concentration and working temperature. Higher thermal conductivity of nanofluid observed at higher volume concentration and temperature as reported by Alirezaie et al., [50]. However, the thermal conductivity decreased with the increase in the percentage of Ethylene Glycol in the mixture of Ethylene Glycol/water as a base fluid [51]. Furthermore, the thermal conductivity of oil-based nanofluid decreases at the temperature greater than $180^{\circ} \mathrm{C}$ due to the vaporization of organic oil which regards its flash point [52]. Abubakar et al., [53] stated that $0.08 \%$ of temperature reduction at $0.8 \%$ volume fraction of $\mathrm{Fe}_{3} \mathrm{O}_{4}$ in water over the pure water in microchannel heat sinks thermal analysis.

In addition, certain nanoparticles such as MWCNTs and Ag possess higher thermal conductivity compared to other nanoparticles. Therefore, the dispersion of these nanoparticles would significantly enhance the thermal conductivity of nanofluids over base fluid. However, obtaining the stability of these nanofluids is always challenging which is associated with the higher density. In order to avoid instability conditions of suspension, nanoparticles concentration should be managed wisely as they have significant influence on the thermal conductivity and stability. On the other hand, the effect of nanoparticle shape is significant for nanofluid thermal conductivity. For instance, as reported by Jeong et al., [54] that nearly rectangular $\mathrm{ZnO}$ exhibited $18 \%$ of thermal conductivity enhancement over the sphere shape of the same material which recorded $15 \%$ enhancement at the same concentration of $5.0 \mathrm{vol} \%$. This is due to a higher interface area which directly increasing surface interaction and the possibility of higher contact area with other materials in transferring the heat $[55,56]$. According to Cui et al., [57], nanofluids that consist of the cylindrical shapes of nanoparticles displays higher thermal conductivity rather than sphere shape due to micro-convection activities of rotational motion in nanofluids. However, Kim et al., [58] mentioned that the thermal conductivity of nanofluids increases with decreasing nanoparticles size. With smaller particle sizes, the suspension would be more stable and the chemical interaction could happen even in confine space. 
Nevertheless, according to Jeong et al., [54], the nanoparticle shape is more dominant in getting higher thermal conductivity of nanofluids than the particle size which regards specifically to $\mathrm{ZnO}$ and more study should be conducted for other nanoparticles. The summary of thermal conductivity and viscosity enhancement findings for single and hybrid nanofluid are shown in Table 1 and Table 2 respectively.

Table 1

Summary of single nanofluid thermal conductivity and viscosity maximum enhancement

\begin{tabular}{|c|c|c|c|c|c|c|}
\hline Author & Base Fluid & $\begin{array}{l}\text { Nano- } \\
\text { particles }\end{array}$ & $\begin{array}{l}\text { Volume } \\
\text { Fraction }\end{array}$ & $\begin{array}{l}\text { Measurement } \\
\text { Temperature }\end{array}$ & $\begin{array}{l}\text { Measurement } \\
\text { Property }\end{array}$ & $\begin{array}{l}\text { Maximum } \\
\text { Enhancement } \\
(\%)\end{array}$ \\
\hline Sundar et al., [59] & $\begin{array}{l}\text { Ethylene } \\
\text { Glycol (EG): } \\
\text { Water } \\
20: 80 \% \\
40: 60 \% \\
80: 20 \%\end{array}$ & $\mathrm{Al}_{2} \mathrm{O}_{3}$ & $\begin{array}{l}0.0 \%, \\
0.3 \%, \\
0.6 \%, \\
0.8 \%, \\
1.0 \%, \\
1.5 \%\end{array}$ & $20^{\circ} \mathrm{C}-60^{\circ} \mathrm{C}$ & $\begin{array}{l}\text { Thermal } \\
\text { Conductivity } \\
\text { Dynamic } \\
\text { Viscosity }\end{array}$ & $\begin{array}{l}32.26 \% \text { of } 1.5 \\
\text { vol\% at } 60^{\circ} \mathrm{C} \\
1.37 \text { times } \\
\text { compared to } \\
\text { base fluid }\end{array}$ \\
\hline Chen et al., [60] & $\begin{array}{l}\text { Natural } \\
\text { Seawater }\end{array}$ & $\mathrm{SiC}$ & $0.0 \%-1.0 \%$ & $10^{\circ} \mathrm{C}-50^{\circ} \mathrm{C}$ & $\begin{array}{l}\text { Thermal } \\
\text { Conductivity }\end{array}$ & $5.2 \%$ \\
\hline $\begin{array}{l}\text { Huminic et al., } \\
\text { [61] }\end{array}$ & $\begin{array}{l}\text { Distilled } \\
\text { Water }\end{array}$ & $\mathrm{SiC}$ & $\begin{array}{l}0.5 w t \%, 1.0 \\
w t \%\end{array}$ & $20^{\circ} \mathrm{C}-50^{\circ} \mathrm{C}$ & $\begin{array}{l}\text { Thermal } \\
\text { conductivity } \\
\text { Dynamic } \\
\text { Viscosity }\end{array}$ & $\begin{array}{l}17.62 \% \text { of } 1.0 \\
\text { wt } \% \text { at } 50 \mathrm{C} \\
17.62 \%\end{array}$ \\
\hline $\begin{array}{l}\text { Al-Waeli et al., } \\
\text { [62] }\end{array}$ & $\begin{array}{l}\text { Deionized } \\
\text { water }\end{array}$ & $\mathrm{SiC}$ & $1 \%-4 \%$ & $25^{\circ} \mathrm{C}-60^{\circ} \mathrm{C}$ & $\begin{array}{l}\text { Thermal } \\
\text { Conductivity }\end{array}$ & $8.2 \%$ \\
\hline Yu et al., [63] & $\begin{array}{l}\text { Ethylene } \\
\text { Glycol (EG) }\end{array}$ & $\mathrm{ZnO}$ & $0 \%-5 \%$ & $10^{\circ} \mathrm{C}-60^{\circ} \mathrm{C}$ & $\begin{array}{l}\text { Thermal } \\
\text { Conductivity }\end{array}$ & $\begin{array}{l}26.5 \% \text { of } 5 \\
\text { vol\% }\end{array}$ \\
\hline $\begin{array}{l}\text { Suganthi and } \\
\text { Rajan [64] }\end{array}$ & Water & $\mathrm{ZnO}$ & $0.25 \%-2 \%$ & $35^{\circ} \mathrm{C}-55^{\circ} \mathrm{C}$ & $\begin{array}{l}\text { Dynamic } \\
\text { Viscosity }\end{array}$ & $28 \%$ \\
\hline Nadooshan [65] & $\begin{array}{l}\text { Ethylene } \\
\text { Glycol (EG) }\end{array}$ & $\mathrm{ZnO}$ & $\begin{array}{l}0.125 \%- \\
4.0 \%\end{array}$ & $20^{\circ} \mathrm{C}-50^{\circ} \mathrm{C}$ & $\begin{array}{l}\text { Thermal } \\
\text { Conductivity }\end{array}$ & $\begin{array}{l}20 \% \text { of } 4 \\
\text { vol. } \%\end{array}$ \\
\hline Lim et al., [15] & $\begin{array}{l}\text { Water- } \\
\text { Ethylene } \\
\text { glycol (EG) }\end{array}$ & $\mathrm{Al}_{2} \mathrm{O}_{3}$ & $\begin{array}{l}0.2 \%, 0.4 \%, \\
0.6 \%, 0.8 \%, \\
1 \%\end{array}$ & $15^{\circ} \mathrm{C}-55^{\circ} \mathrm{C}$ & $\begin{array}{l}\text { Thermal } \\
\text { Conductivity } \\
\text { Dynamic } \\
\text { Viscosity } \\
\text { Convective Heat } \\
\text { Transfer } \\
\text { Coefficient }\end{array}$ & $\begin{array}{l}10 \% \text { of } 1 \text { vol\% } \\
39 \% \text { of } 1 \text { vol\% } \\
25.4 \% \text { of } 1 \\
\text { vol\% }\end{array}$ \\
\hline $\begin{array}{l}\text { Andhare and Raju } \\
\text { [66] }\end{array}$ & $\begin{array}{l}\text { Distilled } \\
\text { Water }\end{array}$ & $\begin{array}{l}\text { MWCNT } \\
\text { S }\end{array}$ & $0.2 \%$ & $\begin{array}{l}33^{\circ} \mathrm{C}, 40^{\circ} \mathrm{C}, 50^{\circ} \\
\mathrm{C}\end{array}$ & $\begin{array}{l}\text { Thermal } \\
\text { Conductivity } \\
\text { Contact Angle }\end{array}$ & $\begin{array}{l}36 \% \\
\text { reduced by } \\
33.3 \%\end{array}$ \\
\hline $\begin{array}{l}\text { Murshed et al., } \\
\text { [67] }\end{array}$ & $\begin{array}{l}\text { De-ionized } \\
\text { Water }\end{array}$ & $\mathrm{TiO}_{2}$ & $\begin{array}{l}0.001 \%- \\
0.05 \%\end{array}$ & $10^{\circ} \mathrm{C}-60^{\circ} \mathrm{C}$ & $\begin{array}{l}\text { Thermal } \\
\text { Conductivity }\end{array}$ & $17 \%$ \\
\hline Najiha et al., [68] & $\begin{array}{l}\text { De-ionized } \\
\text { Water }\end{array}$ & $\mathrm{TiO}_{2}$ & $\begin{array}{l}0.5 \%, 2.5 \%, 4 . \\
5 \%\end{array}$ & $30^{\circ} \mathrm{C}-60^{\circ} \mathrm{C}$ & $\begin{array}{l}\text { Thermal } \\
\text { Conductivity }\end{array}$ & $11.4 \%$ \\
\hline Nazari et al., [14] & Water & $\begin{array}{l}\mathrm{Al}_{2} \mathrm{O}_{3} \\
\mathrm{CNT}\end{array}$ & $\begin{array}{l}0.1 \%, 0.25 \%, \\
0.5 \%\end{array}$ & $20^{\circ} \mathrm{C}-50^{\circ} \mathrm{C}$ & $\begin{array}{l}\text { Heat Transfer } \\
\text { Coefficient } \\
\text { Heat Transfer } \\
\text { Coefficient }\end{array}$ & $\begin{array}{l}6 \% \text { of } \\
0.5 \mathrm{vol} . \% \\
13 \% \text { of } \\
0.25 \mathrm{vol} . \%\end{array}$ \\
\hline $\begin{array}{l}\text { Xuan and Li et al., } \\
\text { [19] }\end{array}$ & Water & $\mathrm{Cu}$ & $2 w t \%-9 w t \%$ & $15^{\circ} \mathrm{C}-55^{\circ} \mathrm{C}$ & $\begin{array}{l}\text { Thermal } \\
\text { Conductivity }\end{array}$ & $\begin{array}{l}1.78 \text { times } \\
\text { higher than } \\
\text { base fluid }\end{array}$ \\
\hline $\begin{array}{l}\text { Baghbanzadeh et } \\
\text { al., [69] }\end{array}$ & $\begin{array}{l}\text { Distilled } \\
\text { Water }\end{array}$ & $\begin{array}{l}\text { MWCNT } \\
\text { S }\end{array}$ & $\begin{array}{l}0 \text { wt. } \% \text { - } 1 \\
\text { wt.\% }\end{array}$ & $27^{\circ} \mathrm{C}, 40^{\circ} \mathrm{C}$ & $\begin{array}{l}\text { Thermal } \\
\text { Conductivity }\end{array}$ & $23.3 \%$ \\
\hline
\end{tabular}




\begin{tabular}{|c|c|c|c|c|c|c|}
\hline Ilyas et al., [70] & $\begin{array}{l}\text { Thermal Oil } \\
\text { (THO) }\end{array}$ & $\begin{array}{l}\text { MWCNT } \\
\mathrm{S}\end{array}$ & $\begin{array}{l}0 \text { wt.\% - } 1 \\
\text { wt.\% }\end{array}$ & $25^{\circ} \mathrm{C}-60^{\circ} \mathrm{C}$ & $\begin{array}{l}\text { Thermal } \\
\text { Conductivity }\end{array}$ & $\begin{array}{l}28.7 \% \text { of } \\
1 w t . \%\end{array}$ \\
\hline Li et al., [71] & $\begin{array}{l}\text { Waste } \\
\text { Cooking Oil }\end{array}$ & $\mathrm{SiC}$ & $0.02 \%-0.1 \%$ & $25^{\circ} \mathrm{C}-60^{\circ} \mathrm{C}$ & $\begin{array}{l}\text { Thermal } \\
\text { Conductivity }\end{array}$ & $23 \%$ \\
\hline $\begin{array}{l}\text { Khedkar et al., } \\
\text { [72] }\end{array}$ & Paraffin Oil & $\mathrm{Fe}_{3} \mathrm{O}_{4}$ & $0.01 \%-0.1 \%$ & $27^{\circ} \mathrm{C}$ & $\begin{array}{l}\text { Thermal } \\
\text { Conductivity }\end{array}$ & $20 \%$ \\
\hline $\begin{array}{l}\text { Abareshi et al., } \\
\text { [73] }\end{array}$ & $\begin{array}{l}\text { Deionized } \\
\text { Water }\end{array}$ & $\mathrm{Fe}_{3} \mathrm{O}_{4}$ & $0 \%-3 \%$ & $10^{\circ} \mathrm{C}-40^{\circ} \mathrm{C}$ & $\begin{array}{l}\text { Thermal } \\
\text { Conductivity }\end{array}$ & $\begin{array}{l}11.5 \% \text { of } 3 \\
\text { vol. } \% \text { at } 40^{\circ} \mathrm{C}\end{array}$ \\
\hline
\end{tabular}

Table 2

Summary of hybrid nanofluid thermal conductivity and viscosity maximum enhancement

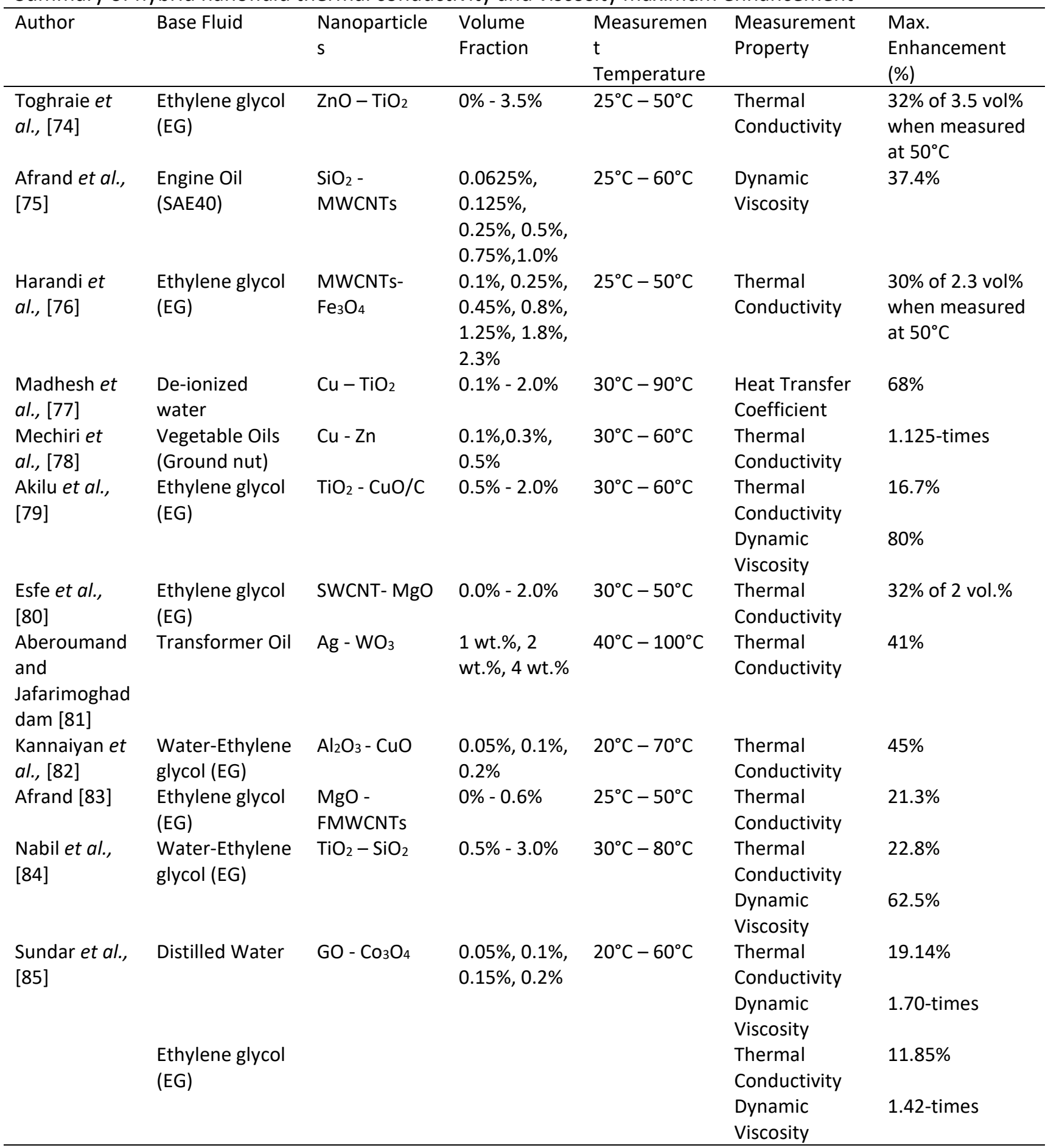




\begin{tabular}{|c|c|c|c|c|c|c|}
\hline $\begin{array}{l}\text { Wei et al., } \\
\text { [86] }\end{array}$ & Diathermic Oil & $\mathrm{SiC}-\mathrm{TiO}_{2}$ & $0.1 \%-1.0 \%$ & $10^{\circ} \mathrm{C}-50^{\circ} \mathrm{C}$ & $\begin{array}{l}\text { Thermal } \\
\text { Conductivity }\end{array}$ & $8.39 \%$ \\
\hline $\begin{array}{l}\text { Sundar et al., } \\
\text { [87] }\end{array}$ & $\begin{array}{l}\text { Water-Ethylene } \\
\text { glycol (EG) }\end{array}$ & $\mathrm{ND}-\mathrm{Co}_{3} \mathrm{O}_{4}$ & $0 \%-0.15 \%$ & $20^{\circ} \mathrm{C}-60^{\circ} \mathrm{C}$ & $\begin{array}{l}\text { Thermal } \\
\text { Conductivity } \\
\text { Dynamic } \\
\text { Viscosity }\end{array}$ & $\begin{array}{l}16.0 \% \text { at } 60^{\circ} \mathrm{C} \\
1.51 \text {-times at } \\
60^{\circ} \mathrm{C}\end{array}$ \\
\hline $\begin{array}{l}\text { Yarmand et } \\
\text { al., [88] }\end{array}$ & Distilled Water & GNP - Pt & $0.0 \%-0.1 \%$ & $20^{\circ} \mathrm{C}-40^{\circ} \mathrm{C}$ & $\begin{array}{l}\text { Thermal } \\
\text { Conductivity } \\
\text { Dynamic } \\
\text { Viscosity }\end{array}$ & $\begin{array}{l}17.77 \% \text { of } 0.1 \\
\text { vol. } \% \text { at } 40^{\circ} \mathrm{C} \\
33 \% \text { of } 0,1 \% \text { at } \\
40^{\circ} \mathrm{C}\end{array}$ \\
\hline $\begin{array}{l}\text { Soltani and } \\
\text { Akbari [89] }\end{array}$ & $\begin{array}{l}\text { Ethylene glycol } \\
\text { (EG) }\end{array}$ & $\begin{array}{l}\text { MgO - } \\
\text { MWCNT }\end{array}$ & $0.1 \%-1.0 \%$ & $30^{\circ} \mathrm{C}-60^{\circ} \mathrm{C}$ & $\begin{array}{l}\text { Dynamic } \\
\text { Viscosity }\end{array}$ & $168 \%$ \\
\hline $\begin{array}{l}\text { Sundar et al., } \\
\text { [90] }\end{array}$ & $\begin{array}{l}\text { Water-Ethylene } \\
\text { glycol (EG) }\end{array}$ & $\mathrm{ND}-\mathrm{Fe}_{3} \mathrm{O}_{4}$ & $\begin{array}{l}0.005 \%, \\
0.1 \%, 0.2 \%\end{array}$ & $20^{\circ} \mathrm{C}-60^{\circ} \mathrm{C}$ & $\begin{array}{l}\text { Thermal } \\
\text { Conductivity } \\
\text { Dynamic } \\
\text { Viscosity }\end{array}$ & $\begin{array}{l}17.8 \% \\
2.19 \text {-times }\end{array}$ \\
\hline
\end{tabular}

Table 1 and Table 2 show the important findings of nanofluids thermal conductivity and dynamic viscosity. It has summarized the maximum enhancement based on experimental studies. The maximum enhancement of thermal conductivity for single nanofluid is $36 \%$ of MWCNTs in distilled water. Meanwhile, the enhancement of viscosity for single nanofluid is recorded $39 \%$ of $\mathrm{Al}_{2} \mathrm{O}_{3}$ in water-EG over the base fluid. On the other hand, the hybrid nanofluids exhibit superior thermal conductivity over single nanofluid where the maximum enhancement is recorded $68 \%$ of $\mathrm{Cu}-\mathrm{TiO}_{2}$ in deionized water. Furthermore, the maximum enhancement percentage for hybrid nanofluid viscosity is recorded $168 \%$ of MgO-MWCNT in ethylene glycol. Based on experimental results, hybrid nanofluids have greater potential as the future working fluid in cooling and heating which regards the enhancement of thermal-physical properties of single nanofluids.

\subsection{Thermal Conductivity Model}

The overall cost of experiments nowadays is getting more expensive and conducting the experiments may consume a lot of time. Hence, the prediction correlation models of nanofluid thermal conductivity developed by scholars may assist in calculating the important property such as thermal conductivity. Table 3 shows thermal conductivity models developed by scholars based on actual experimental data. The regression models may differ due to different considerations of nanoparticle characteristics such as size, shape, different materials and coating layer as well as the type of the base fluid and its composition when preparing the fluid. However, the results obtained using the correlation model should be verified with the actual experimental data.

Table 3

Summary of nanofluids thermal conductivity models developed by various scholars

Author Thermal Conductivity Models Description


$\begin{array}{ll}\text { Maxwell } & \frac{k_{n f}}{k}=\frac{k_{s}+2 k+2 \varphi\left(k_{s}-k\right)}{k s_{s}+2 k-\varphi\left(k_{s}-k\right)}\end{array}$

$\begin{aligned} & \text { Hamilton } \\ & \text { and Crosser }\end{aligned} \frac{k_{n f}}{k}=\frac{k_{s}+(n-1) k+(n-1) \varphi\left(k_{s}-k\right)}{k s_{s}+(n-1) k-\varphi\left(k_{s}-k\right)}$

[92]

Yu and Choi

[93]

$$
\begin{aligned}
& k_{p e}=\frac{\left[2(1-\gamma)+(1+\beta)^{3}(1+2 \gamma)\right] \gamma}{-(1-\gamma)+(1+\beta)^{3}+(1+2 \gamma)} k_{p} \\
& \frac{k_{n f}}{k_{f}}=\frac{k_{p e}+2 k_{b}+2\left(k_{p e}-k_{p}\right)(1+\beta)^{3} \emptyset}{k_{p e}+2 k_{b}-\left(k_{p e}-k_{b}\right)(1+\beta)^{3} \emptyset}
\end{aligned}
$$

Bruggeman [94]

$$
\frac{k_{n f}}{k_{b f}}=\frac{1}{4}(3 \emptyset-1) k_{n p}+\left[(2-3 \emptyset) k_{b f}\right]+\frac{k_{b f}}{4} \sqrt{\Delta}
$$

where,

$$
\begin{aligned}
& \Delta=\left[(3 \emptyset-1)^{2}\left(\frac{k_{n p}}{k_{b f}}\right)^{2}+\left[(2-3 \emptyset)^{2}+2(2+9 \emptyset-\right.\right. \\
& \left.\left.\left.9 \emptyset^{2}\right)\right] \frac{k_{n p}}{k_{b f}}\right]
\end{aligned}
$$

$\begin{array}{ll}\text { Feng et al., } & \frac{k_{s}}{k_{f}}=\frac{k_{p}+2 k_{f}-2 \varphi\left(1+\lambda_{\text {nano }}\right)^{3}\left(k_{f}-k_{p}\right)}{k_{p}+2 k_{f}+\varphi\left(1+\lambda_{\text {nano }}\right)^{3}\left(k_{f}-k_{p}\right)}\end{array}$

$\begin{aligned} & \text { Timofeeva } \\ & \text { et al., [95] }\end{aligned} \quad \frac{k_{\text {eff }}}{k_{f}}=(1+3 \phi)$

$\begin{array}{ll}\text { Vafaei et al., } & \frac{k_{n f}}{k_{b f}}=0.9787+\exp \left(0.3081 \phi^{0.3097}-0.002 T\right)\end{array}$
The first model and always referred to

define the effective thermal conductivity of combination liquid and solid suspensions. Where $\varphi$ is the particle sphericity.

This model considers a non-spherical nanoparticle and a shape factor that affects the liquid-solid thermal conductivity. Where $\mathrm{n}$ is the empirical shape factor given by $3 / \phi$ and $\varphi$ is the particle sphericity where 1 for the spherical and 0.5 for the cylindrical shape respectively.

The nanolayers at solid/liquid interface take into considerations when defining the equivalent thermal conductivity kpe. Where $\gamma$ is the ratio of nanolayer thermal conductivity to particle thermal conductivity $\left(\gamma=k_{p e} / k\right)$. In extreme case, $k_{p e}=k$, thus, $\gamma$ is equivalent to 1 . Where $\phi$ is the particle volume concentration and $B$ is the ratio of thickness layer, $h$ over particle radius, $r(B=h / r)$.

Bruggeman has proposed a better model than two models above to predict the thermal conductivity at any $\mathrm{v} / \mathrm{v} \%$ and valid for spherical shape nanoparticle. Where $\phi$ is the particle volume concentration, $k_{n p}$ is the thermal conductivity of nanoparticle and $k_{b f}$ is the thermal conductivity of the base fluid.

A model that considered of nanolayer, $\lambda_{\text {nano }}$ which is referred to the ratio of nanoparticle thickness and radius $\left(\lambda_{\text {nano }}=\frac{t_{p}}{r_{p}}\right)$ in determining the nanofluid thermal conductivity. The model considers geometry, agglomeration state and surface resistance of nanoparticles in determining the efficiency of thermal conductivity. $k_{\text {eff }}$ is an effective thermal conductivity. Where $\phi$ is the particle volume concentration.

The model is based on optimum conditions using an artificial neural network and can be used to predict hybrid nanofluids. Where $\phi$ is the particle volume concentration and $\mathrm{T}$ is measured temperature.

\subsection{Dynamic Viscosity of Nanofluids}


Viscosity is a measure of the liquid tendency against the flow. It is important rheology property of nanofluid that affecting the convective heat transfer coefficient [96]. When the liquid viscosity is constant over the shear rate, thus the liquid can be classified as Newtonian fluid as reported by Ghasemi and Karimipour [97]. On the other hand, when the fluid viscosity is changing over the shear rate, then the fluid is classified as Non-Newtonian fluid [98]. The viscometer is a key measurement instrument to measure the nanofluid viscosity. In order to measure nanofluids' dynamic viscosity, viscometer such as NDJ-9s rotating viscometer and Brookfield can be used [49,52-55]. For nanofluids, volume concentration is the most important factor whether it can be classified as Newtonian or NonNewtonian fluid. For instance, Hong et al., [99] found that $\mathrm{FeO}_{4} /$ water nanofluid exhibited Newtonian at a low concentration but behave non-Newtonian at a higher volume concentration due to the viscosity is changing over shear rate. The viscosity level in nanofluid is crucial because it may lead to high-pressure drop and subsequently more energy is required for pumping power prior to supply the cutting fluid. Based on the experimental investigation done by Pak and Cho [100], there was no significant influence on fluid viscosity based on different $\mathrm{pH}$ values and there was an additional $31 \%$ of the pumping penalty at a $3 \%$ of volume concentration where the fluid velocity remains constant.

However, nanofluid with higher viscosity has better performance for the lubricating effect due to it has a better contact area between the cutting tooltip and the workpiece $[101,102]$. This led to wettability effects of nanofluids on the contact surface. Moreover, higher viscosity prevents nanofluid from flowing freely out of the contact zone. This relationship between cutting fluid viscosity and surface tension is associated with cutting fluid wetting and spray characteristics. Sundar et al., [21] reported out that the viscosity of nanofluids is directly proportional to volume concentration. In contrast, the viscosity is inversely proportional to the temperature. Brownian motion effect where the molecules move freely and randomly could be attributed to the inverse relationship between temperature and viscosity [103].

\subsection{Viscosity Model}

Besides the thermal conductivity model, scholars since the 1950s have developed a viscosity model for predicting working fluid viscosity based on experimental works as can be seen in Table 4 . This is an attempted to model the important property of nanofluids by mathematical regressions. Hence, the property can be calculated from the mathematical modelling.

Table 4

Summary of nanofluids dynamic viscosity models developed by various scholars

Author Viscosity Models $\quad$ Description




\begin{tabular}{ll}
\hline Pak and Cho & $\mu_{\text {eff }}=\mu_{\text {eff }}\left(1+39.11 \phi+533.9 \phi^{2}\right)$ \\
[100] & \\
Einstein [104] & $\mu_{\text {eff }}=\mu(1+2.5 \phi), \phi<0.05$ \\
Roscoe [105] & $\mu_{\text {eff }}=\mu_{f}\left(1-\frac{\phi}{\phi_{m}}\right)^{-2.5}$ \\
& \\
Koo and & $\mu_{\text {Brownian }}=$ \\
Kleinstreuer & $5 x 10^{4} \beta \rho m \phi_{p} \sqrt{\frac{K_{g} T}{2 \rho_{p} r_{p}}\left[\left(-13463+17223 \phi_{p}\right)+\left(0.4705-6.04 \phi_{p}\right) T\right.}$ \\
[106] &
\end{tabular}

$\begin{aligned} & \text { Brinkman } \\ & {[107]}\end{aligned} \quad \frac{\mu_{e f f}}{\mu_{f}}=\frac{1}{(1-\phi)^{2.5}}$

Batchelor $\quad \mu_{\text {eff }}=1+2.5 \phi+6.5 \phi^{2}$ [108]
This model is referred to as two different metallic particles at room temperature. Where $\phi$ is the particle volume concentration.

Based on the suspension of spherical particles.

Where $\phi$ is the particle volume concentration. A model for equal size rigid spheres and for all concentrations. Where $\phi$ is the particle volume concentration.

Small scale interaction may occur between the hot and cold regions. Thus, temperature, particle size and volume fraction also affect the viscosity. Where $\phi$ is the particle volume concentration, $T$ is temperature, $\rho$ is particle density and $r$ is particle radius.

This model is extended from Einstein's model which dilutes copper, gold, CNT suspension. The model includes base fluid, nanoparticle viscosity and volume fraction respectively. Where $\phi$ is the particle volume concentration. The effect of Brownian motion takes into consideration and it was extended from Einstein's model. Where $\phi$ is the particle volume concentration.

The suitability of the models as shown in Table 3 and Table 4 is relied more on the type of base fluid, size of the nanoparticle, type of nanoparticle, volume concentration and addition of surfactant. Moreover, the accuracy of these models had been tested which close to the experimental results. However, these thermal-physical modelling can be expanded by considering additional factors such as measured temperature, coated and uncoated particles and different shapes when more than one nanoparticle is dispersed in the base fluid. However, the experimental works must be performed in the sense that a deviation of the results can be avoided. Therefore, a newly developed regression model can be examined proven by conducting an experimental study to ensure the models and the results are valid. Recently, many researchers have developed empirical correlation models using different methods like genetic algorithms and artificial neural networks. The objective is to generate 
mathematical modelling that will be represented nanofluids' prediction of thermal conductivity and dynamic viscosity.

\section{Conclusion}

The capability of nanofluid in enhancing thermal and rheology properties is really encouraging for the next generation of the working fluid. Even though the pressure drops increases with higher nanofluid viscosity however the presence of more than one type of nanoparticles in preparing nanofluid can further enhance the base fluid heat transfer capability. Due to the pressure drop, more energy is required for circulating the nanofluids. This circumstance might affect the pump specifically where the pump is overworking in supplying the nanofluid consistently into the working zone. For that reason, the viscosity of hybrid nanofluid must be controlled wisely in getting a suitable range of viscosity level. Furthermore, appropriate selection of nanoparticle materials, shape and size as well as type of base fluids, with or without surfactant is crucial to get the optimum condition of nanofluid in terms of physical, thermal and rheological properties. From the literature review, it can be concluded that hybrid nanofluids exhibit better performance than single nanofluid and base fluid. Therefore, hybrid nanofluids have greater potential as the future working fluid in cooling and heating which regards the enhancement of thermal-physical properties of single nanofluids. Thus, more experimental works must be carried out to further understand the behaviour of hybrid nanofluids in terms of the effect of nanoparticle shape, size, concentration and the application of surfactant particularly on both thermal conductivity and dynamic viscosity as well as to explore its great potential. With the huge potential of hybrid nanofluids in terms of thermal-rheology properties, the elevation of overall engineering performance is realistic to be achieved.

\section{Acknowledgement}

The authors gratefully acknowledge the support of Universiti Malaysia Pahang for providing research grants RDU1703135 and UMP LEAP-3 flagship project number RDU172203 as well as PGRS 190338 to conduct hybrid nanofluids related research for manufacturing application.

\section{References}

[1] Kim, Hyun-Joon, Kuk-Jin Seo, Kyeong Hee Kang, and Dae-Eun Kim. "Nano-lubrication: A review." International Journal of Precision Engineering and Manufacturing 17, no. 6 (2016): 829-841.

https://doi.org/10.1007/s12541-016-0102-0

[2] Choi, Stephen U. S., and Jeffrey A. Eastman. "Enhancing thermal conductivity of fluids with nanoparticles." ASME International Mechanical Engineering Congress and Exposition 231 (1995): 99-105.

[3] Sharma, Anuj Kumar, Arun Kumar Tiwari, and Amit Rai Dixit. "Progress of nanofluid application in machining: a review." Materials and Manufacturing Processes 30, no. 7 (2015): 813-828. https://doi.org/10.1080/10426914.2014.973583

[4] Hamzah, Muhammad Hafiz, Nor Azwadi Che Sidik, Tan Lit Ken, Rizalman Mamat, and G. Najafi. "Factors affecting the performance of hybrid nanofluids: a comprehensive review." International Journal of Heat and Mass Transfer 115 (2017): 630-646. https://doi.org/10.1016/i.ijheatmasstransfer.2017.07.021

[5] Alawi, Omer A., Nor Azwadi Che Sidik, Hong Wei Xian, Tung Hao Kean, and Salim Newaz Kazi. "Thermal conductivity and viscosity models of metallic oxides nanofluids." International Journal of Heat and Mass Transfer 116 (2018): 1314-1325. https://doi.org/10.1016/j.ijheatmasstransfer.2017.09.133

[6] Pryazhnikov, M. I., A. V. Minakov, V. Ya Rudyak, and D. V. Guzei. "Thermal conductivity measurements of nanofluids." International Journal of Heat and Mass Transfer 104 (2017): 1275-1282. https://doi.org/10.1016/i.ijheatmasstransfer.2016.09.080

[7] Choi, S. U. S., Z. G. Zhang, WLockwoodFE Yu, F. E. Lockwood, and E. A. Grulke. "Anomalous thermal conductivity enhancement in nanotube suspensions." Applied Physics Letters 79, no. 14 (2001): 2252-2254. 
https://doi.org/10.1063/1.1408272

[8] Fotowat, Shahram, Serena Askar, Mohammed Ismail, and Amir Fartaj. "A study on corrosion effects of a water based nanofluid for enhanced thermal energy applications." Sustainable Energy Technologies and Assessments 24 (2017): 39-44.

https://doi.org/10.1016/i.seta.2017.02.001

[9] Rashmi, W., A. F. Ismail, M. Khalid, A. Anuar, and T. Yusaf. "Investigating corrosion effects and heat transfer enhancement in smaller size radiators using CNT-nanofluids." Journal of Materials Science 49, no. 13 (2014): 45444551.

https://doi.org/10.1007/s10853-014-8154-y

[10] Elcioglu, Elif Begum, Almila Guvenc Yazicioglu, Alpaslan Turgut, and Ahmet Sermet Anagun. "Experimental study and Taguchi Analysis on alumina-water nanofluid viscosity." Applied Thermal Engineering 128 (2018): 973-981. https://doi.org/10.1016/j.applthermaleng.2017.09.013

[11] Murshed, S. M. Sohel, and Patrice Estellé. "A state of the art review on viscosity of nanofluids." Renewable and Sustainable Energy Reviews 76 (2017): 1134-1152.

https://doi.org/10.1016/i.rser.2017.03.113

[12] Nabil, M. F., W. H. Azmi, K. A. Hamid, N. N. M. Zawawi, G. Priyandoko, and R. Mamat. "Thermo-physical properties of hybrid nanofluids and hybrid nanolubricants: a comprehensive review on performance." International Communications in Heat and Mass Transfer 83 (2017): 30-39.

https://doi.org/10.1016/i.icheatmasstransfer.2017.03.008

[13] Sidik, Nor Azwadi Che, Tung Hao Kean, Hoong Kee Chow, Aravinthan Rajaandra, Saidur Rahman, and Jesbains Kaur. "Performance enhancement of cold thermal energy storage system using nanofluid phase change materials: a review." International Communications in Heat and Mass Transfer 94 (2018): 85-95.

https://doi.org/10.1016/i.icheatmasstransfer.2018.03.024

[14] Nazari, M., M. Karami, and M. Ashouri. "Comparing the thermal performance of water, Ethylene Glycol, Alumina and CNT nanofluids in CPU cooling: Experimental study." Experimental Thermal and Fluid Science 57 (2014): 371377.

https://doi.org/10.1016/i.expthermflusci.2014.06.003

[15] Lim, S. K., W. H. Azmi, and A. R. Yusoff. "Investigation of thermal conductivity and viscosity of Al2O3/water-ethylene glycol mixture nanocoolant for cooling channel of hot-press forming die application." International Communications in Heat and Mass Transfer 78 (2016): 182-189.

https://doi.org/10.1016/j.icheatmasstransfer.2016.09.018

[16] Wang, Yaogang, Changhe Li, Yanbin Zhang, Benkai Li, Min Yang, Xianpeng Zhang, Shuming Guo, Guotao Liu, and Mingge Zhai. "Comparative evaluation of the lubricating properties of vegetable-oil-based nanofluids between frictional test and grinding experiment." Journal of Manufacturing Processes 26 (2017): 94-104. https://doi.org/10.1016/i.jmapro.2017.02.001

[17] Singh, Rabesh Kumar, Anuj Kumar Sharma, Amit Rai Dixit, Arun Kumar Tiwari, Alokesh Pramanik, and Amitava Mandal. "Performance evaluation of alumina-graphene hybrid nano-cutting fluid in hard turning." Journal of Cleaner Production 162 (2017): 830-845.

https://doi.org/10.1016/i.jclepro.2017.06.104

[18] Settu, S., and M. Nandagopal. "Experimental Investigation On Performance Of Milling Operation Using Vegetable Oil Based Nano-Cutting Fluid And Its Process Parameters Optimization Using Taguchi And Anova." Discovery 23, no. 78 (2014): 89-93.

[19] Xuan, Yimin, and Qiang Li. "Heat transfer enhancement of nanofluids." International Journal of Heat and Fluid Flow 21, no. 1 (2000): 58-64. https://doi.org/10.1016/S0142-727X(99)00067-3

[20] Minh, Duc Tran, Long Tran The, and Ngoc Tran Bao. "Performance of Al2O3 nanofluids in minimum quantity lubrication in hard milling of 60Si2Mn steel using cemented carbide tools." Advances in Mechanical Engineering 9, no. 7 (2017): 1687814017710618.

https://doi.org/10.1177/1687814017710618

[21] Sundar, L. Syam, K. V. Sharma, Manoj K. Singh, and A. C. M. Sousa. "Hybrid nanofluids preparation, thermal properties, heat transfer and friction factor-a review." Renewable and Sustainable Energy Reviews 68 (2017): 185198.

https://doi.org/10.1016/i.rser.2016.09.108

[22] Krishna, P. Vamsi, R. R. Srikant, R. Padmini, and J. L. P. P. Viswaditya. "Application of nanomaterials as coolants/lubricants in machining." In International Conference on Advanced Nanomaterials \& Emerging Engineering Technologies, pp. 674-682. IEEE, 2013. 
[23] Zhang, Yanbin, Changhe Li, Dongzhou Jia, Dongkun Zhang, and Xiaowei Zhang. "Experimental evaluation of the lubrication performance of MoS2/CNT nanofluid for minimal quantity lubrication in Ni-based alloy grinding." International Journal of Machine Tools and Manufacture 99 (2015): 19-33.

https://doi.org/10.1016/j.ijmachtools.2015.09.003

[24] Wang, Yaogang, Changhe Li, Yanbin Zhang, Benkai Li, Min Yang, Xianpeng Zhang, Shuming Guo, and Guotao Liu. "Experimental evaluation of the lubrication properties of the wheel/workpiece interface in MQL grinding with different nanofluids." Tribology International 99 (2016): 198-210.

https://doi.org/10.1016/j.triboint.2016.03.023

[25] Gavili, Anwar, Fatemeh Zabihi, Taghi Dallali Isfahani, and Jamshid Sabbaghzadeh. "The thermal conductivity of water base ferrofluids under magnetic field." Experimental Thermal and Fluid Science 41 (2012): 94-98.

https://doi.org/10.1016/i.expthermflusci.2012.03.016

[26] Vafaei, Masoud, Masoud Afrand, Nima Sina, Rasool Kalbasi, Forough Sourani, and Hamid Teimouri. "Evaluation of thermal conductivity of MgO-MWCNTs/EG hybrid nanofluids based on experimental data by selecting optimal artificial neural networks." Physica E: Low-dimensional Systems and Nanostructures 85 (2017): 90-96.

https://doi.org/10.1016/i.physe.2016.08.020

[27] Sundar, L. Syam, E. Venkata Ramana, M. K. Singh, and A. C. M. De Sousa. "Viscosity of low volume concentrations of magnetic Fe304 nanoparticles dispersed in ethylene glycol and water mixture." Chemical Physics Letters 554 (2012): 236-242. https://doi.org/10.1016/i.cplett.2012.10.042

[28] Li, Benkai, Changhe Li, Yanbin Zhang, Yaogang Wang, Dongzhou Jia, Min Yang, Naiqing Zhang, Qidong Wu, Zhiguang Han, and Kai Sun. "Heat transfer performance of MQL grinding with different nanofluids for Ni-based alloys using vegetable oil." Journal of Cleaner Production 154 (2017): 1-11.

https://doi.org/10.1016/i.jclepro.2017.03.213

[29] Guo, Shaojun, Shaojun Dong, and Erkang Wang. "Gold/platinum hybrid nanoparticles supported on multiwalled carbon nanotube/silica coaxial nanocables: preparation and application as electrocatalysts for oxygen reduction." The Journal of Physical Chemistry C 112, no. 7 (2008): 2389-2393. https://doi.org/10.1021/ip0772629

[30] Raju, Roja Abraham, Atul Andhare, and Neelesh Kumar Sahu. "Performance of multi-walled carbon nanotube-based nanofluid in turning operation." Materials and Manufacturing Processes 32, no. 13 (2017): 1490-1496. https://doi.org/10.1080/10426914.2017.1279291

[31] Sadri, Rad, Goodarz Ahmadi, Hussein Togun, Mahidzal Dahari, Salim Newaz Kazi, Emad Sadeghinezhad, and Nashrul Zubir. "An experimental study on thermal conductivity and viscosity of nanofluids containing carbon nanotubes." Nanoscale Research Letters 9, no. 1 (2014): 151-166. https://doi.org/10.1186/1556-276X-9-151

[32] Kwak, Kiyuel, and Chongyoup Kim. "Viscosity and thermal conductivity of copper oxide nanofluid dispersed in ethylene glycol." Korea-Australia Rheology Journal 17, no. 2 (2005): 35-40.

[33] Sharma, Anuj Kumar, Arun Kumar Tiwari, and Amit Rai Dixit. "Characterization of TiO2, Al2O3 and SiO2 nanoparticle based cutting fluids." Materials Today: Proceedings 3, no. 6 (2016): 1890-1898.

https://doi.org/10.1016/i.matpr.2016.04.089

[34] Su, Yu, Le Gong, and Dandan Chen. "An investigation on tribological properties and lubrication mechanism of graphite nanoparticles as vegetable based oil additive." Journal of Nanomaterials (2015): 1-7. https://doi.org/10.1155/2015/276753

[35] Sayuti, Mohd, Ooi Ming Erh, Ahmed AD Sarhan, and Mohd Hamdi. "Investigation on the morphology of the machined surface in end milling of aerospace AL6061-T6 for novel uses of SiO2 nanolubrication system." Journal of Cleaner Production 66 (2014): 655-663.

https://doi.org/10.1016/j.jclepro.2013.11.058

[36] Yogeswaran, M., K. Kadirgama, M. M. Rahman, and R. Devarajan. "Temperature analysis when using ethyleneglycol-based TiO2 as a new coolant for milling." International Journal of Automotive and Mechanical Engineering 11, no. 1 (2015): 2272-81.

https://doi.org/10.15282/ijame.11.2015.10.0191

[37] Esfe, Mohammad Hemmat, Hossein Rostamian, Alireza Shabani-Samghabadi, and Ali Akbar Abbasian Arani. "Application of three-level general factorial design approach for thermal conductivity of MgO/water nanofluids." Applied Thermal Engineering 127 (2017): 1194-1199. https://doi.org/10.1016/i.applthermaleng.2017.07.211

[38] Babu, J. A. Ranga, K. Kiran Kumar, and S. Srinivasa Rao. "State-of-art review on hybrid nanofluids." Renewable and Sustainable Energy Reviews 77 (2017): 551-565. https://doi.org/10.1016/i.rser.2017.04.040 
[39] Zhang, Xianpeng, Changhe Li, Yanbin Zhang, Dongzhou Jia, Benkai Li, Yaogang Wang, Min Yang, Yali Hou, and Xiaowei Zhang. "Performances of Al $2 \mathrm{O} 3 / \mathrm{SiC}$ hybrid nanofluids in minimum-quantity lubrication grinding." The International Journal of Advanced Manufacturing Technology 86, no. 9-12 (2016): 3427-3441.

https://doi.org/10.1007/s00170-016-8453-3

[40] Huang, Dan, Zan Wu, and Bengt Sunden. "Effects of hybrid nanofluid mixture in plate heat exchangers." Experimental Thermal and Fluid Science 72 (2016): 190-196.

https://doi.org/10.1016/i.expthermflusci.2015.11.009

[41] Sahoo, Rashmi R., and Jahar Sarkar. "Heat transfer performance characteristics of hybrid nanofluids as coolant in louvered fin automotive radiator." Heat and Mass Transfer 53, no. 6 (2017): 1923-1931.

https://doi.org/10.1007/s00231-016-1951-x

[42] Xie, Hongmei, Bin Jiang, Bo Liu, Qinghang Wang, Junyao Xu, and Fusheng Pan. "An investigation on the tribological performances of the SiO2/MoS2 hybrid nanofluids for magnesium alloy-steel contacts." Nanoscale Research Letters 11, no. 1 (2016): 1-17. https://doi.org/10.1186/s11671-016-1546-y

[43] Selvakumar, P., and S. Suresh. "Thermal performance of ethylene glycol based nanofluids in an electronic heat sink." Journal of Nanoscience and Nanotechnology 14, no. 3 (2014): 2325-2333.

https://doi.org/10.1166/inn.2014.8470

[44] Rabiei, Farshad, A. R. Rahimi, and Mohamad Jafar Hadad. "Performance improvement of eco-friendly MQL technique by using hybrid nanofluid and ultrasonic-assisted grinding." The International Journal of Advanced Manufacturing Technology 93, no. 1-4 (2017): 1001-1015. https://doi.org/10.1007/s00170-017-0521-9

[45] Tullius, Toni K., and Yildiz Bayazitoglu. "Analysis of a hybrid nanofluid exposed to radiation." Numerical Heat Transfer, Part B: Fundamentals 69, no. 4 (2016): 271-286. https://doi.org/10.1080/10407790.2015.1104210

[46] Sarkar, Jahar, Pradyumna Ghosh, and Arjumand Adil. "A review on hybrid nanofluids: recent research, development and applications." Renewable and Sustainable Energy Reviews 43 (2015): 164-177. https://doi.org/10.1016/i.rser.2014.11.023

[47] Çengel, Yunus A. Heat Transfer: A Practical Approach. 2nd Edition. McGraw-Hill, 2003.

[48] Tawfik, Mohamed M. "Experimental studies of nanofluid thermal conductivity enhancement and applications: A review." Renewable and Sustainable Energy Reviews 75 (2017): 1239-1253. https://doi.org/10.1016/j.rser.2016.11.111

[49] Maheshwary, P. B., C. C. Handa, and K. R. Nemade. "A comprehensive study of effect of concentration, particle size and particle shape on thermal conductivity of titania/water based nanofluid." Applied Thermal Engineering 119 (2017): 79-88. https://doi.org/10.1016/i.applthermaleng.2017.03.054

[50] Alirezaie, Ali, Mohammad Hadi Hajmohammad, Mohammad Reza Hassani Ahangar, and Mohammad Hemmat Esfe. "Price-performance evaluation of thermal conductivity enhancement of nanofluids with different particle sizes." Applied Thermal Engineering 128 (2018): 373-380. https://doi.org/10.1016/i.applthermaleng.2017.08.143

[51] Guo, Yufeng, Tongtong Zhang, Dongrui Zhang, and Qi Wang. "Experimental investigation of thermal and electrical conductivity of silicon oxide nanofluids in ethylene glycol/water mixture." International Journal of Heat and Mass Transfer 117 (2018): 280-286. https://doi.org/10.1016/j.ijheatmasstransfer.2017.09.091

[52] Zeng, Yuan-Xian, Xiu-Wen Zhong, Zhao-Qing Liu, Shuang Chen, and Nan Li. "Preparation and enhancement of thermal conductivity of heat transfer oil-based MoS2 nanofluids." Journal of Nanomaterials (2013). https://doi.org/10.1155/2013/270490

[53] Abubakar, S., Nor Azwadi Che Sidik, and A. Ahmad. "The use of Fe3O4-H2O4 nanofluid for heat transfer enhancement in rectangular microchannel heatsink." Journal of Advanced Research in Materials Science 23, no. 1 (2016): 15-24.

[54] Jeong, Jisun, Chengguo Li, Younghwan Kwon, Jaekeun Lee, Soo Hyung Kim, and Rin Yun. "Particle shape effect on the viscosity and thermal conductivity of ZnO nanofluids." International Journal of Refrigeration 36, no. 8 (2013): 2233-2241. https://doi.org/10.1016/j.ijrefrig.2013.07.024

[55] Akbulut, Mustafa, Anna R. Godfrey Alig, Younjin Min, Nataly Belman, Magdalene Reynolds, Yuval Golan, and Jacob Israelachvili. "Forces between surfaces across nanoparticle solutions: role of size, shape, and concentration." Langmuir 23, no. 7 (2007): 3961-3969.

https://doi.org/10.1021/la062613g 
[56] Ghosh, M. M., S. Ghosh, and S. K. Pabi. "Effects of particle shape and fluid temperature on heat-transfer characteristics of nanofluids." Journal of Materials Engineering and Performance 22, no. 6 (2013): 1525-1529. https://doi.org/10.1007/s11665-012-0441-7

[57] Cui, Wenzheng, Minli Bai, Jizu Lv, Guojie Li, and Xiaojie Li. "On the influencing factors and strengthening mechanism for thermal conductivity of nanofluids by molecular dynamics simulation." Industrial \& Engineering Chemistry Research 50, no. 23 (2011): 13568-13575. https://doi.org/10.1021/ie201307w

[58] Kim, Sang Hyun, Sun Rock Choi, and Dongsik Kim. "Thermal conductivity of metal-oxide nanofluids: particle size dependence and effect of laser irradiation." Journal of Heat Transfer 129, no. 3 (2007): 298-307. https://doi.org/10.1115/1.2427071

[59] Sundar, L. Syam, E. Venkata Ramana, Manoj K. Singh, and Antonio C. M. Sousa. "Thermal conductivity and viscosity of stabilized ethylene glycol and water mixture Al2O3 nanofluids for heat transfer applications: An experimental study." International Communications in Heat and Mass Transfer 56 (2014): 86-95. https://doi.org/10.1016/j.icheatmasstransfer.2014.06.009

[60] Chen, Wenjing, Changjun Zou, Xiaoke Li, and Lu Li. "Experimental investigation of SiC nanofluids for solar distillation system: Stability, optical properties and thermal conductivity with saline water-based fluid." International Journal of Heat and Mass Transfer 107 (2017): 264-270.

https://doi.org/10.1016/i.ijheatmasstransfer.2016.11.048

[61] Huminic, Gabriela, Angel Huminic, Claudiu Fleaca, Florian Dumitrache, and Ion Morjan. "Thermo-physical properties of water based SiC nanofluids for heat transfer applications." International Communications in Heat and Mass Transfer 84 (2017): 94-101.

https://doi.org/10.1016/j.icheatmasstransfer.2017.04.006

[62] Al-Waeli, Ali H. A., K. Sopian, Miqdam T. Chaichan, Hussein A. Kazem, Husam Abdulrasool Hasan, and Ali Najah AlShamani. "An experimental investigation of SiC nanofluid as a base-fluid for a photovoltaic thermal PV/T system." Energy Conversion and Management 142 (2017): 547-558. https://doi.org/10.1016/i.enconman.2017.03.076

[63] Yu, Wei, Huaqing Xie, Lifei Chen, and Yang Li. "Investigation of thermal conductivity and viscosity of ethylene glycol based ZnO nanofluid." Thermochimica Acta 491, no. 1-2 (2009): 92-96.

https://doi.org/10.1016/j.tca.2009.03.007

[64] Suganthi, K. S., and K. S. Rajan. "Temperature induced changes in ZnO-water nanofluid: zeta potential, size distribution and viscosity profiles." International Journal of Heat and Mass Transfer 55, no. 25-26 (2012): 79697980.

https://doi.org/10.1016/j.ijheatmasstransfer.2012.08.032

[65] Nadooshan, Afshin Ahmadi. "An experimental correlation approach for predicting thermal conductivity of waterEG based nanofluids of zinc oxide." Physica E: Low-dimensional Systems and Nanostructures 87 (2017): 15-19. https://doi.org/10.1016/i.physe.2016.11.004

[66] Andhare, Atul B., and Roja Abraham Raju. "Properties of dispersion of multiwalled carbon nanotubes as cutting fluid." Tribology Transactions 59, no. 4 (2016): 663-670.

https://doi.org/10.1080/10402004.2015.1102369

[67] Murshed, S. M. S., K. C. Leong, and C. Yang. "Enhanced thermal conductivity of TiO2-water based nanofluids." International Journal of Thermal Sciences 44, no. 4 (2005): 367-373. https://doi.org/10.1016/j.ijthermalsci.2004.12.005

[68] Najiha, M. S., M. M. Rahman, and K. Kadirgama. "Performance of water-based TiO2 nanofluid during the minimum quantity lubrication machining of aluminium alloy, AA6061-T6." Journal of Cleaner Production 135 (2016): 16231636.

https://doi.org/10.1016/j.jclepro.2015.12.015

[69] Baghbanzadeh, Mohammadali, Alimorad Rashidi, Davood Rashtchian, Roghayeh Lotfi, and Azadeh Amrollahi. "Synthesis of spherical silica/multiwall carbon nanotubes hybrid nanostructures and investigation of thermal conductivity of related nanofluids." Thermochimica Acta 549 (2012): 87-94.

https://doi.org/10.1016/i.tca.2012.09.006

[70] Ilyas, Suhaib Umer, Rajashekhar Pendyala, and Marneni Narahari. "Stability and thermal analysis of MWCNTthermal oil-based nanofluids." Colloids and Surfaces A: Physicochemical and Engineering Aspects 527 (2017): 1122. https://doi.org/10.1016/i.colsurfa.2017.05.004

[71] Li, Wenjing, Changjun Zou, and Xiaoke Li. "Thermo-physical properties of waste cooking oil-based nanofluids." Applied Thermal Engineering 112 (2017): 784-792.

https://doi.org/10.1016/j.applthermaleng.2016.10.136 
[72] Khedkar, Rohit S., A. Sai Kiran, Shriram S. Sonawane, Kailas Wasewar, and Suresh S. Umre. "Thermo-Physical Characterization of Paraffin based Fe304 Nanofluids." Procedia Engineering 51 (2013): 342-346. https://doi.org/10.1016/j.proeng.2013.01.047

[73] Abareshi, Maryam, Elaheh K. Goharshadi, Seyed Mojtaba Zebarjad, Hassan Khandan Fadafan, and Abbas Youssefi. "Fabrication, characterization and measurement of thermal conductivity of Fe3O4 nanofluids." Journal of Magnetism and Magnetic Materials 322, no. 24 (2010): 3895-3901. https://doi.org/10.1016/i.jmmm.2010.08.016

[74] Toghraie, Davood, Vahid Avalin Chaharsoghi, and Masoud Afrand. "Measurement of thermal conductivity of ZnOTiO 2/EG hybrid nanofluid." Journal of Thermal Analysis and Calorimetry 125, no. 1 (2016): 527-535. https://doi.org/10.1007/s10973-016-5436-4

[75] Afrand, Masoud, Karim Nazari Najafabadi, and Mohammad Akbari. "Effects of temperature and solid volume fraction on viscosity of SiO2-MWCNTs/SAE40 hybrid nanofluid as a coolant and lubricant in heat engines." Applied Thermal Engineering 102 (2016): 45-54. https://doi.org/10.1016/j.applthermaleng.2016.04.002

[76] Harandi, Saeed Sarbolookzadeh, Arash Karimipour, Masoud Afrand, Mohammad Akbari, and Annunziata D'Orazio. "An experimental study on thermal conductivity of F-MWCNTs-Fe304/EG hybrid nanofluid: effects of temperature and concentration." International Communications in Heat and Mass Transfer 76 (2016): 171-177. https://doi.org/10.1016/j.icheatmasstransfer.2016.05.029

[77] Madhesh, D., R. Parameshwaran, and S. Kalaiselvam. "Experimental investigation on convective heat transfer and rheological characteristics of Cu-TiO2 hybrid nanofluids." Experimental Thermal and Fluid Science 52 (2014): 104115.

https://doi.org/10.1016/i.expthermflusci.2013.08.026

[78] Mechiri, S. K., V. Vasu, and A. Venu Gopal. "Investigation of thermal conductivity and rheological properties of vegetable oil based hybrid nanofluids containing $\mathrm{Cu}-\mathrm{Zn}$ hybrid nanoparticles." Experimental Heat Transfer 30, no. 3 (2017): 205-217. https://doi.org/10.1080/08916152.2016.1233147

[79] Akilu, Suleiman, Aklilu Tesfamichael Baheta, and K. V. Sharma. "Experimental measurements of thermal conductivity and viscosity of ethylene glycol-based hybrid nanofluid with TiO2-CuO/C inclusions." Journal of Molecular Liquids 246 (2017): 396-405.

https://doi.org/10.1016/i.molliq.2017.09.017

[80] Esfe, Mohammad Hemmat, Ali Alirezaie, and Mousa Rejvani. "An applicable study on the thermal conductivity of SWCNT-MgO hybrid nanofluid and price-performance analysis for energy management." Applied Thermal Engineering 111 (2017): 1202-1210. https://doi.org/10.1016/j.applthermaleng.2016.09.091

[81] Aberoumand, Sadegh, and Amin Jafarimoghaddam. "Tungsten (III) oxide (WO3)-Silver/transformer oil hybrid nanofluid: Preparation, stability, thermal conductivity and dielectric strength." Alexandria Engineering Journal 57, no. 1 (2018): 169-174. https://doi.org/10.1016/i.aej.2016.11.003

[82] Kannaiyan, Sathishkumar, Chitra Boobalan, Avinash Umasankaran, Abhaiguru Ravirajan, Sneha Sathyan, and Tiju Thomas. "Comparison of experimental and calculated thermophysical properties of alumina/cupric oxide hybrid nanofluids." Journal of Molecular Liquids 244 (2017): 469-477. https://doi.org/10.1016/i.molliq.2017.09.035

[83] Afrand, Masoud. "Experimental study on thermal conductivity of ethylene glycol containing hybrid nano-additives and development of a new correlation." Applied Thermal Engineering 110 (2017): 1111-1119. https://doi.org/10.1016/i.applthermaleng.2016.09.024

[84] Nabil, M. F., W. H. Azmi, K. Abdul Hamid, Rizalman Mamat, and Ftwi Y. Hagos. "An experimental study on the thermal conductivity and dynamic viscosity of TiO2-SiO2 nanofluids in water: ethylene glycol mixture." International Communications in Heat and Mass Transfer 86 (2017): 181-189. https://doi.org/10.1016/j.icheatmasstransfer.2017.05.024

[85] Sundar, L. Syam, Manoj K. Singh, M. C. Ferro, and Antonio C. M. Sousa. "Experimental investigation of the thermal transport properties of graphene oxide/Co3O4 hybrid nanofluids." International Communications in Heat and Mass Transfer 84 (2017): 1-10. https://doi.org/10.1016/j.icheatmasstransfer.2017.03.001

[86] Wei, Baojie, Changjun Zou, Xihang Yuan, and Xiaoke Li. "Thermo-physical property evaluation of diathermic oil based hybrid nanofluids for heat transfer applications." International Journal of Heat and Mass Transfer 107 (2017): 281-287.

https://doi.org/10.1016/j.ijheatmasstransfer.2016.11.044 
[87] Sundar, L. Syam, G. O. Irurueta, E. Venkata Ramana, Manoj K. Singh, and A. C. M. Sousa. "Thermal conductivity and viscosity of hybrid nanfluids prepared with magnetic nanodiamond-cobalt oxide (ND-Co3O4) nanocomposite." Case Studies in Thermal Engineering 7 (2016): 66-77.

https://doi.org/10.1016/i.csite.2016.03.001

[88] Yarmand, Hooman, Samira Gharehkhani, Seyed Farid Seyed Shirazi, Marjan Goodarzi, Ahmad Amiri, Wail Sami Sarsam, Maryam Sadat Alehashem, Mahidzal Dahari, and S. N. Kazi. "Study of synthesis, stability and thermophysical properties of graphene nanoplatelet/platinum hybrid nanofluid." International Communications in Heat and Mass Transfer 77 (2016): 15-21.

https://doi.org/10.1016/i.icheatmasstransfer.2016.07.010

[89] Soltani, Omid, and Mohammad Akbari. "Effects of temperature and particles concentration on the dynamic viscosity of MgO-MWCNT/ethylene glycol hybrid nanofluid: experimental study." Physica E: Low-dimensional Systems and Nanostructures 84 (2016): 564-570.

https://doi.org/10.1016/j.physe.2016.06.015

[90] Sundar, L. Syam, E. Venkata Ramana, M. P. F. Graça, Manoj K. Singh, and Antonio C. M. Sousa. "NanodiamondFe304 nanofluids: preparation and measurement of viscosity, electrical and thermal conductivities." International Communications in Heat and Mass Transfer 73 (2016): 62-74.

https://doi.org/10.1016/j.icheatmasstransfer.2016.02.013

[91] Maxwell, James Clerk. A Treatise on Electricity and Magnetism: Vol. 1. Oxford: Clarendon Press (1873): $360-366$.

[92] Hamilton, R. L., and O. K. Crosser. "Thermal conductivity of heterogeneous two-component systems." Industrial \& Engineering Chemistry Fundamentals 1, no. 3 (1962): 187-191.

https://doi.org/10.1021/i160003a005

[93] Yu, W., and S. U. S. Choi. "The role of interfacial layers in the enhanced thermal conductivity of nanofluids: a renovated Maxwell model." Journal of Nanoparticle Research 5, no. 1-2 (2003): 167-171. https://doi.org/10.1023/A:1024438603801

[94] Bruggeman, D. A. G. "Calculation of various physics constants in heterogenous substances I Dielectricity constants and conductivity of mixed bodies from isotropic substances." Annalen der Physik 416, no. 7 (1935): 636-664. https://doi.org/10.1002/andp.19354160705

[95] Timofeeva, Elena V., Alexei N. Gavrilov, James M. McCloskey, Yuriy V. Tolmachev, Samuel Sprunt, Lena M. Lopatina, and Jonathan V. Selinger. "Thermal conductivity and particle agglomeration in alumina nanofluids: experiment and theory." Physical Review E 76, no. 6 (2007): 061203.

https://doi.org/10.1103/PhysRevE.76.061203

[96] Jama, Mohamoud, Tejvir Singh, Seifelislam Mahmoud Gamaleldin, Muammer Koc, Ayman Samara, Rima J. Isaifan, and Muataz A. Atieh. "Critical review on nanofluids: preparation, characterization, and applications." Journal of Nanomaterials (2016). https://doi.org/10.1155/2016/6717624

[97] Ghasemi, Samad, and Arash Karimipour. "Experimental investigation of the effects of temperature and mass fraction on the dynamic viscosity of CuO-paraffin nanofluid." Applied Thermal Engineering 128 (2018): 189-197. https://doi.org/10.1016/i.applthermaleng.2017.09.021

[98] Devendiran, Dhinesh Kumar, and Valan Arasu Amirtham. "A review on preparation, characterization, properties and applications of nanofluids." Renewable and Sustainable Energy Reviews 60 (2016): 21-40. https://doi.org/10.1016/i.rser.2016.01.055

[99] Hong, R. Y., Z. Q. Ren, Y. P. Han, H. Z. Li, Y. Zheng, and J. Ding. "Rheological properties of water-based Fe304 ferrofluids." Chemical Engineering Science 62, no. 21 (2007): 5912-5924. https://doi.org/10.1016/j.ces.2007.06.010

[100] Pak, Bock Choon, and Young I. Cho. "Hydrodynamic and heat transfer study of dispersed fluids with submicron metallic oxide particles." Experimental Heat Transfer an International Journal 11, no. 2 (1998): 151-170. https://doi.org/10.1080/08916159808946559

[101] Su, Yu, Le Gong, Bi Li, Zhiqiang Liu, and Dandan Chen. "Performance evaluation of nanofluid MQL with vegetablebased oil and ester oil as base fluids in turning." The International Journal of Advanced Manufacturing Technology 83, no. 9-12 (2016): 2083-2089. https://doi.org/10.1007/s00170-015-7730-x

[102] Zhang, Yanbin, Changhe Li, Dongzhou Jia, Dongkun Zhang, and Xiaowei Zhang. "Experimental evaluation of MoS2 nanoparticles in jet MQL grinding with different types of vegetable oil as base oil." Journal of Cleaner Production 87 (2015): 930-940. https://doi.org/10.1016/i.jclepro.2014.10.027

[103] Jang, Seok Pil, and Stephen U. S. Choi. "Role of Brownian motion in the enhanced thermal conductivity of nanofluids." Applied Physics Letters 84, no. 21 (2004): 4316-4318. 
https://doi.org/10.1063/1.1756684

[104] Einstein, Albert. "A new determination of molecular dimensions." Annalen der Physik 19 (1906): 289-306. https://doi.org/10.1002/andp.19063240204

[105] Roscoe, R. "The viscosity of suspensions of rigid spheres." British Journal of Applied Physics 3, no. 8 (1952): 267269.

https://doi.org/10.1088/0508-3443/3/8/306

[106] Koo, Junemoo, and Clement Kleinstreuer. "A new thermal conductivity model for nanofluids." Journal of Nanoparticle Research 6, no. 6 (2004): 577-588. https://doi.org/10.1007/s11051-004-3170-5

[107] Brinkman, H. C. "The viscosity of concentrated suspensions and solutions." The Journal of Chemical Physics 20, no. 4 (1952): 571. https://doi.org/10.1063/1.1700493

[108] Batchelor, G. K. "The effect of Brownian motion on the bulk stress in a suspension of spherical particles." Journal of Fluid Mechanics 83, no. 1 (1977): 97-117. https://doi.org/10.1017/S0022112077001062

[109] Feng, Yongjin, Boming Yu, Peng Xu, and Mingqing Zou. "The effective thermal conductivity of nanofluids based on the nanolayer and the aggregation of nanoparticles." Journal of Physics D: Applied Physics 40, no. 10 (2007): 31643171.

https://doi.org/10.1088/5002237274010020 